\title{
Features of Formation of Structureless Reefs near the Mainland and Island Coast of Vietnam
}

\section{Yuri Ya. Latypov}

A.V. Zhirmunsky Institute of Marine Biology, Far East Branch, Russian Academy of Sciences, Vladivostok, Russia Email: Itpv@mail.ru

Received 28 March 2016; accepted 11 April 2016; published 14 April 2016

Copyright (C) 2016 by author and OALib.

This work is licensed under the Creative Commons Attribution International License (CC BY). http://creativecommons.org/licenses/by/4.0/

(c) †) Open Access

\begin{abstract}
We study structureless reefs of the mainland and island coastlines of Vietnam. It is shown that this type of reefs has stable species composition and community structure, like in similar bionomic zones in conventional reefs. They are characterized by high species diversity, including more than a third of all reef-building scleractinian of the Pacific. Non-structural reefs are characterized by the same trophic relations of the inner and outer parts of the reef, from the standpoint of a clear scheme of bionomic zoning on reefs throughout the Indo-Pacific in general.
\end{abstract}

\section{Keywords}

Research, Structureless Reefs, Corals, Vietnam

Subject Areas: Biodiversity, Ecosystem Science, Marine Biology

\section{Introduction}

The specificity of geomorphology and climatic conditions allow dividing the World Ocean reefs, Vietnam in particular, in two types. Reefs of the first type are called structural reefs [1], and have expressed morphological (conventional lagoon, reef flat etc.) and bionomic zoning, as well as powerful corallogenous structure of the reef framework. They are common in the tropical areas of the World Ocean. In the second type of reefs, morphological zoning is feeble or not expressed at all. Their thin carbonate deposits form as a layer of coral settlements that almost do not change the profile of the substrate (Figure 1). However, their distinct bionomic zonation, which is expressed through the specific composition of species and their ratio, is comparable to that of the structural reefs. Those are the so-called unstructured or incrusting (crust) reefs, which can often be found among the monsoon-type reefs [1]-[3]. Such reefs spread along the entire coast of Vietnam and its islands, and are formed near rock and rocky coasts. Different types of reefs, as well as the composition and structure that 


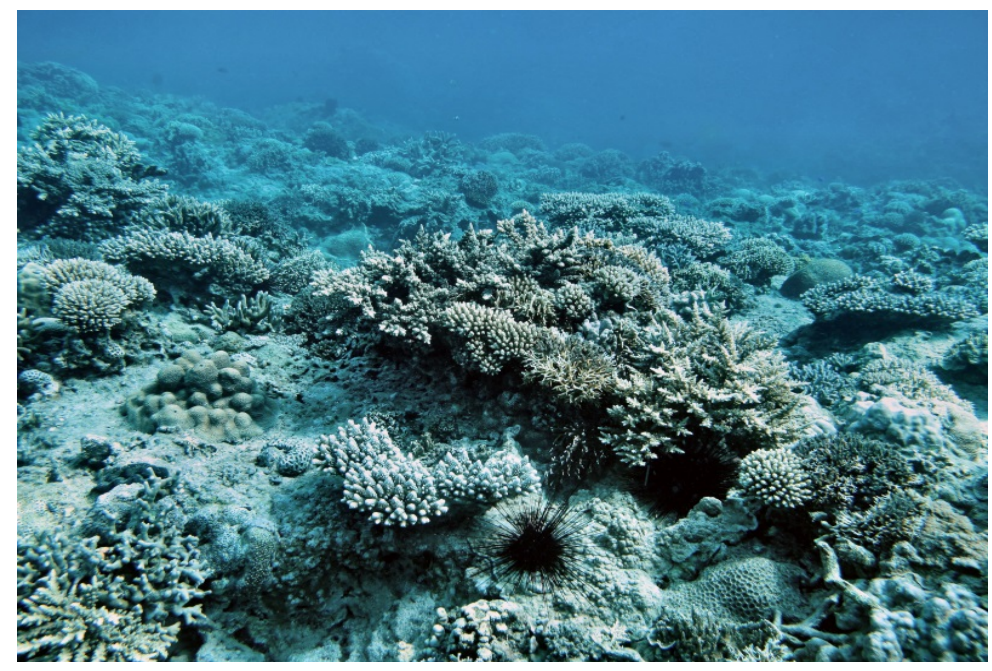

Figure 1. Substrate coating corals on the reef Honden, depth $4 \mathrm{~m}$.

form their communities, have been repeatedly described in detail in various articles and monographs [3] [4]-[6] [7] [8]. Information on unstructured reefs is rather limited [9]-[12]. New data provided in this article will serve as a complement to the knowledge about the structure of the coral reefs and their communities, existing global resource information about corals and reefs of the Indo-Pacific.

\section{Materials and Methods}

In 1987-2013, using autonomous diving equipment, a study was carried out to research the species composition and distribution of scleractinian, mass species of macrobenthos and community structure in the adjacent structureless reefs along the continental and island coastlines of Vietnam Gulf of Tonkin to the Gulf of Thailand. In this work, the conventional hydrobiological method was used, involving accounting framework and transects [13]. Along the 100 - 200-meter transects, using a frame divided into 100 squares of an area of $10 \mathrm{~cm}^{2}$ ( $1 \%$ coverage of the substrate area), the researchers assessed the number of common species of mollusks and echinoderms, branched, massive, encrusting and funnel colonies of scleractinian, as well as the degree of coverage of the substrate. The species diversity index was determined by the formula: $H=-\sum[(n i / N)(\ln n i / N)]$, where $H$ is the Shannon index; $n i$ is the number of individuals belonging to $i$ species; $N$ is the total number of individuals [14]. To analyze the similarity of a complex of coral, the program Statistica 6.0 was used. For off-site analysis of the composition of communities and the study of scleractinian species diversity, more than 2000 photographs of coral colonies, of the overall picture of reef communities and underwater landscapes were used, obtained by Olympus and Lumix cameras.

\section{Results}

Almost on all surveyed reefs, 25 types dominated or were the most frequent ones: macrophytes Padina australis; clams Tridacna maxima, T. crocea and Lambis chiragra; echinoderms Diadema setosum, Holothuria atra, Stichopus chloronatus, Linckia laevigata and Ophiocoma nigra; Alcyonaria Sinularia dura and Sarcophyton trochelioforum; scleractinians Acropora microphthalma, A. cytherea, A. valenciennesi, Montipora aequituberculata, M. hispida, M. grisea, Hydnophora rigida, Porites cylindrica, P. rus, Platygyra daedalea, Leptoria phrygia, Favia speciosa, F. maxima and Pavona cactus. Monospecific settlements of $75-100 \mathrm{~m}^{2}$ were formed by A. cytherea, A. microphthalma, which, together with $P$. cactus, H. rigida, M. aequituberculata and M. grisea formed dense populations of tens of square meters. Coral communities were usually formed by 140 - 170 scleractinian species, $40 \%-42 \%$ of those species are ubiquitous (see Table 1 ).

On the studied structureless reefs no distinct morphological zoning was revealed. However, well-defined composition and structure of corals and associated corallobionts are quite clearly distinguishable with more distance from the shore. This allows us to define bionomic areas, which are comparable to conventional zoning structural reefs (Figure 2). 
Table 1. List of the most spread scleractinian on some reefs of Vietnam.

\begin{tabular}{|c|c|c|c|c|c|c|}
\hline Species & Honden & Honnai & Katuik & Namsu & Anthoi & Hontrai \\
\hline Psammocora contiqua (Esper, 1797) & + & + & + & + & - & + \\
\hline P. profundacella Gardiner, 1898 & + & + & + & + & + & + \\
\hline Pocillopora damicornis Linnaeus, 1758 & + & + & + & + & - & - \\
\hline P. woodjonesi Vaughan, 1918 & + & + & + & + & + & - \\
\hline Seriatopora hystrix Dana, 1846 & + & + & + & + & - & + \\
\hline S. caliendrum Ehrenberg, 1834 & + & - & + & + & + & + \\
\hline Acropora robusta (Dana, 1846) & + & + & + & + & + & + \\
\hline A. danai (Edwards \& Haime, 1860) & - & + & + & - & + & + \\
\hline A. nobilis (Dana, 1846) & + & + & + & + & + & + \\
\hline A. formosa (Dana, 1846) & + & + & + & + & - & - \\
\hline A. microphthalma (Verrill, 1869) & + & + & - & + & - & + \\
\hline A. valenciennesi (Edwards \& Haime, 1860) & + & + & + & + & + & + \\
\hline A. horrida (Dana, 1846) & - & - & + & + & - & - \\
\hline A. vaughani Wells, 1954 & - & + & - & + & - & - \\
\hline A.aspera (Dana, 1846) & + & + & + & + & + & + \\
\hline A. hyacinthus (Dana, 1846) & + & + & + & + & + & + \\
\hline A. cytherea (Dana, 1846) & + & + & + & + & + & + \\
\hline A. austera (Dana, 1846) & + & - & + & - & + & - \\
\hline A. pulchra (Brook, 1891) & + & + & + & + & - & - \\
\hline A. millepora (Ehrenberg, 1834) & + & + & + & + & + & + \\
\hline A. selago (Studer, 1878) & + & + & + & + & - & - \\
\hline A. cerealis (Dana, 1846) & + & + & + & + & + & + \\
\hline A. nasuta (Dana, 1846) & + & + & + & + & + & - \\
\hline A. nobilis (Dana, 1846) & + & + & + & + & + & - \\
\hline A. diversa (Brook, 1891) & - & + & + & + & - & + \\
\hline A. humilis (Dana, 1846) & + & + & + & + & + & + \\
\hline A. digitifera (Dana, 1846) & + & + & + & + & + & + \\
\hline A. gemmifera (Brook, 1891) & + & + & + & + & + & + \\
\hline A. florida (Dana, 1846) & + & + & + & + & - & - \\
\hline Astreopora ocellata Bernard, 1896 & + & + & - & - & + & + \\
\hline A. myriophthalma (Lamark, 1816) & + & + & + & + & + & + \\
\hline Montipora tuberculosa (Lamark, 1816) & + & + & + & + & + & + \\
\hline M. danae (Edwards \& Haime, 1860) & - & + & + & + & - & - \\
\hline M. venosa (Ehrenberg, 1834) & - & + & - & + & - & + \\
\hline M. caliculata (Dana, 1846) & + & + & + & + & + & + \\
\hline M. hispida (Dana, 1846) & + & + & + & + & + & + \\
\hline M. efflorescens Bernard, 1897 & + & + & + & + & + & + \\
\hline M. australiensis Bernard, 1897 & + & + & + & + & + & + \\
\hline M. grisea Bernard, 1897 & + & + & + & + & + & - \\
\hline M. aequituberculata Bernard, 1897 & + & + & + & - & + & + \\
\hline M. digitata (Dana, 1846) & + & + & + & + & - & - \\
\hline Pavona cactus (Forskal, 1775) & + & - & - & - & - & + \\
\hline P. frondifera Lamark, 1801 & + & + & + & + & + & + \\
\hline
\end{tabular}




\section{Continued}

\begin{tabular}{|c|c|c|c|c|c|c|}
\hline P. explanulata (Lamark, 1816) & + & + & + & + & - & + \\
\hline P. venosa (Ehrenberg, 1834) & - & + & + & + & + & + \\
\hline Leptoseris explanata Yabe \& Sugiyama, 1936 & + & - & + & + & - & + \\
\hline Pseudosiderastrea tayamai Yabe, \& Sug., 1936 & + & + & + & + & + & + \\
\hline Coscinaraea columna (Dana, 1846) & + & + & + & + & - & - \\
\hline Fungia. concina Verrill, 1864 & - & + & + & + & + & + \\
\hline F. scutaria Lamark, 1801 & + & + & + & + & + & + \\
\hline F. fungites (Linnaeus, 1758) & + & + & + & + & + & + \\
\hline Ctenactis echinata (Pallas, 1766) & + & + & - & + & - & - \\
\hline Herpolitha limax (Houttuyn, 1772) & + & + & + & + & + & + \\
\hline H. webwri (Van der Horst, 1921) & + & + & + & + & - & - \\
\hline Sandololitha robusta (Quelch, 1884) & + & + & + & + & + & + \\
\hline S.dentata Quelch, 1884 & + & - & + & + & + & - \\
\hline Polyphyllia talpina (Lamark, 1801) & + & + & - & + & + & + \\
\hline L. undulatum Rehberg, 1892 & + & - & + & + & + & + \\
\hline Podobacia crustacea (Pallas, 1766) & + & + & + & + & + & + \\
\hline Porites lobata Dana, 1846 & + & + & + & + & + & + \\
\hline P. solida (Forskal, 1775) & - & + & - & + & - & + \\
\hline P. murrayensis Vaughan, 1918 & - & + & + & + & + & + \\
\hline P. australiensis Vaughan, 1918 & + & + & + & + & + & + \\
\hline P. lutea Edwards \& Haime, 1858 & + & + & + & + & + & + \\
\hline P. stephensoni Grassland, 1952 & + & + & - & + & - & + \\
\hline P. rus (Forskal, 1775) & + & + & + & + & + & + \\
\hline P. nigrescens Dana, 1846 & + & + & - & + & + & + \\
\hline Goniopora lobata Edwards \& Haime, 1860 & + & + & - & - & - & - \\
\hline G. columna (Dana, 1846) & + & + & - & + & - & - \\
\hline G. djiboutiensisVaughan, 1907 & - & + & + & + & + & + \\
\hline Alveopora allingi Hoifmeister, 1925 & + & + & + & - & - & - \\
\hline Caulastrea tumida, Matthai, 1928 & + & - & - & + & - & + \\
\hline Barabattoia mirabilis Yabe \& Sugiyama, 1941 & + & + & + & - & + & + \\
\hline Favia stelligera (Dana, 1846) & - & - & + & - & + & + \\
\hline F. pallida (Dana, 1846) & - & + & - & + & - & - \\
\hline F. amicorum (Edwards \& Haime, 1850) & + & + & + & + & + & + \\
\hline F. matthai Vaughan, 1918 & + & + & + & + & + & + \\
\hline F. rotumana (Gardiner, 1899) & - & + & + & + & + & + \\
\hline F. maxima Veron \& Pichon, 1977 & + & + & + & + & + & + \\
\hline F. lizardensis Veron \& Pichon, 1977 & + & + & - & + & - & - \\
\hline F. maritima (Nemezo, 1971) & + & + & + & + & + & + \\
\hline Favites chinensis (Verrill, 1866) & - & - & - & + & - & + \\
\hline F. abdita (Elis \& Solander, 1786) & + & + & + & + & + & + \\
\hline F. flexuosa (Dana, 1846) & + & + & - & + & - & - \\
\hline Goniastrea edwardsi Chevalier, 1971 & + & - & + & - & + & + \\
\hline G. retiformis (Lamarck, 1816) & + & + & + & - & + & + \\
\hline G. aspera (Verrill, 1865) & + & + & + & + & + & + \\
\hline
\end{tabular}




\section{Continued}

\begin{tabular}{|c|c|c|c|c|c|c|}
\hline G. pectinata (Ehrenberg, 1834) & + & - & + & + & + & + \\
\hline Platygyra daedalia (Ellis \& Solander, 1786) & + & + & + & + & + & + \\
\hline P. lamellina (Ehrenberg, 1834) & + & + & + & + & + & + \\
\hline P. sinensis (Edwards \& Haime, 1849) & + & + & + & + & + & + \\
\hline P. pini Chevalier, 1975 & + & + & + & + & + & + \\
\hline Leptoria phrygia (Ellis \& Solander, 1786) & + & + & + & + & + & + \\
\hline Hydnophora rigida (Dana, 1846) & - & + & + & + & + & + \\
\hline H. exesa (Pallas, 1766) & + & + & + & - & + & + \\
\hline H. microconos (Lamarck, 1816) & + & + & + & + & + & + \\
\hline Oulastrea crispata (Lamarck, 1816) & + & + & + & + & - & - \\
\hline Leptastrea purpurea (Dana, 1846) & + & + & + & + & + & + \\
\hline L. transversa Klunzinger, 1879 & + & + & - & - & - & - \\
\hline L. pruniosa Crossland, 1952 & - & + & + & + & + & + \\
\hline L. bottae (Edwards \& Haime, 1849) & - & + & + & + & + & + \\
\hline Plesiastrea versipora (Lamarck, 1816) & + & + & + & + & + & + \\
\hline Cyphastrea serailia (Forskal, 1775) & + & + & + & + & + & + \\
\hline C. chalcidicum (Forskal, 1775) & + & + & + & + & + & + \\
\hline C. microphthalma (Lamarck, 1816) & + & + & + & + & + & + \\
\hline Echinopora lamellosa (Esper, 1795) & + & + & + & + & + & + \\
\hline E. hirsutissima Edwards \& Haime, 1849 & - & + & + & + & - & - \\
\hline Moseleyalatistellata Quelch, 1884 & + & + & + & + & + & + \\
\hline Trachyphyllia geoffroyi (Audouin, 1826) & + & + & + & + & + & + \\
\hline Galaxea astreata (Lamarck, 1816) & + & + & + & + & + & + \\
\hline G. fascicularis (Linnaeus, 1797) & + & + & + & + & + & + \\
\hline Acanthasrea echinata (Dana, 1846) & + & + & + & + & + & + \\
\hline Lobophyllia. hemprichii (Ehrenberg, 1834) & + & + & + & + & + & + \\
\hline L. corymbosa (Forskal, 1775) & + & + & + & + & + & + \\
\hline Symphyllia recta (Dana, 1846) & + & + & - & + & + & + \\
\hline S. radians Edwards \& Haime, 1849 & + & - & + & + & - & - \\
\hline S. valenciennessi Edwards \& Haime, 1849 & + & + & + & + & + & + \\
\hline Euphyllia fimbriata (Spengler, 1799) & - & + & + & + & - & - \\
\hline Plerogyra sinuosa (Dana, 1846) & + & - & + & + & + & + \\
\hline Turbinana peltata (Esper, 1794) & + & + & + & + & + & + \\
\hline T. frondens (Dana, 1846) & + & + & + & + & + & + \\
\hline T. reniformis Bernard, 1896 & + & + & + & + & + & + \\
\hline T. mesenterina (Lamarck, 1816) & + & + & + & + & + & + \\
\hline T. crater (Pallas, 1766) & + & + & + & + & + & + \\
\hline
\end{tabular}

Note: Honden and Honnai—Central Vietnam, Katuik—Open Sea of South Vietnam, Namsu and Anthoi—Gulf of Thailand, Hontrai—Tonkin Gulf.

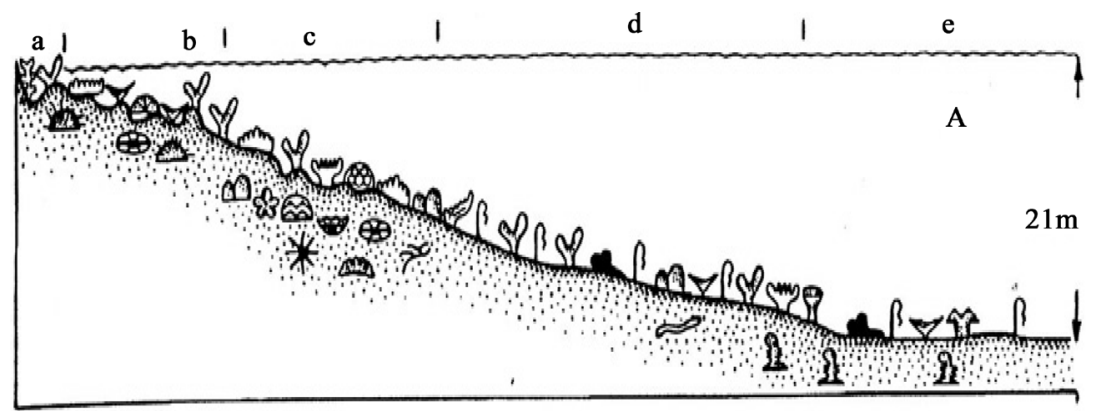

Figure 2. A schematic profile of structureless reef. a — back reef, b - terrace, c —rim reef, d —reef slope, e-for reef platform. 
The coastal community coral-algal zone (back reef) is subject to the maximum wave action and light intensity. Coral communities of this zone are usually formed similarly to those of the boat channel and reef flat [11] [15].

The large variety of macrobenthos species in the area is due to the presence of various terraces, crevices, caves and accumulations of stones, which provide many different oriented substrate surfaces at depths ranging from 0 to $3 \mathrm{~m}$. The main part of the community is represented by alcyonarian $S$. trocheliophorum and large colonies of A. cytherea and A. robusta. Subdominants are Zoanthus sp. and Favites abdita. Colonies of G. fascicularis and Hydnophora exesa may take up to a quarter of the total area of coverage of the substrate. About 30 scleractinian species may be present in this area. In combination with the soft corals, they cover $37 \%$ - $64 \%$ of the substrate surface. In the intertidal zone of the community of common macrophytes Turbinaria crocea, Sargassum polycystum, Padina australis, Caulerpa macrophysa and Amphiroa fragilissima, the latter two species differ have the largest biomass of 1737 and $1283 \mathrm{~g} / \mathrm{m}^{2}$, respectively. The composition and structure of coastal communities are largely determined by the representatives of macrobenthos encountered in this area. These include holothurians H. atra, H. edulis, Stishopus variegates and Bohadschia graeffei $\left(1.5-3 \mathrm{ind} / \mathrm{m}^{2}\right)$, sea urchin D. setosum (up to $27 \mathrm{ind} / \mathrm{m}^{2}$ at a biomass $2438 \mathrm{~g} / \mathrm{m}^{2}$ ) and kauri Cyprea arabica $\left(3-5 \mathrm{ind} / \mathrm{m}^{2}\right)$. Starfish Culcita novaeguineae and gastropod Trochus niloticus are constantly present in this part of the reef.

In the next area of terraces (25 - $50 \mathrm{~m}$ from the shore) is developing a community of Sarcophytum trocheliophorum + Lobophyton pauciflorum. Alcyonarian cover the horizontal surfaces of the rocky substrate almost in a carpet and, on average, have high biomass $\left(12,040 \mathrm{~g} / \mathrm{m}^{2}\right.$ and $10,330 \mathrm{~g} / \mathrm{m}^{2}$ for the first and second types, respectively). These figures, with $100 \%$ coverage of the substrate, reach a maximum biomass of 37,445 and $28,620 \mathrm{~g} / \mathrm{m}^{2}$. In the central part of this community Junceella fragilis can be subdominant, with a population density of $15 \mathrm{ind} / \mathrm{m}^{2}$ and biomass of $556.3 \mathrm{~g} / \mathrm{m}^{2}$. A significant role in the development of soft coral communities belongs to the scleractinian represented by several quite large colonies of $P$. lobata, $P$. lutea, Turbinaria peltata, Diploastrea heliopora, as well as P. daedalea, L. phrygia and F. speciosa, A. cytherea, A. robusta, A. florida. Among the constant components of $S$. trocheliophorum + L. pauciflorum community, we can list the echinoderms D. setosum (5 - $7 \mathrm{ind} / \mathrm{m}^{2}$ ), H. edulis, S. variegates and C. novaeguineae; clams Tridacna squamosa, Arca ventricosa, Beguinia semiorbiculata and Lopha cristagalli and polychaete worms Spirobranchus giganteus, inhabiting a massive colony of Poritidae and Faviidae.

The reef rim on encrusting reefs is not clearly defined. It is marked by the beginning of the wave-cut zone and formed by calcareous coralline algae, as well as by mainly thick-branched and submassive colonies of Acropora, Pocyllopora, Hydnophora, Favia, Favites and Porites.

The composition and structure of coral community on the reef slopes of the studied reefs is comparable to that of the structural zone reefs. This zone is characterized by a rich diversity of species, representing $72.41 \%$ of the total scleractinian species composition and more than 35 genera common to most Indo-Pacific reefs. The most frequently encountered are the following: A. cytherea, A. humilis, A. nobilis, Porites lobata, P. rus, P. cylindrica, Pocillopora hystrix, P. verrucosa, Platygyra daedalea, P. lamellina, D. heliopora, Galaxea fascicularis, Merulina ampliata, Lobophyllia hemprichii and Symphyllia recta various fungiids, such as Fungia scutaria, F. fungites, and Polyphyllia talpina. The degree of substrate coverage by the corals ranged from $40 \%$ to $75 \%$. In the upper part of the most reef slopes, communities Acropora cytherea + Acropora microphthalma or Acropora cytherea + Montipora aequituberculata are formed, covering large areas of the substrate up to $100 \%$. As for the accompanying macrobenthos, the most common were Tridacna maxima $\left(0.1 \mathrm{ind} / \mathrm{m}^{2}\right)$, gastropods Lambis hiragra $\left(0.2 \mathrm{ind} / \mathrm{m}^{2}\right), T$. niloticus and T. maculatus $\left(0.1 .5 \mathrm{ind} / \mathrm{m}^{2}\right)$, single Cyprea tigris and C. arabica, echinoderms D. setosum (3-5 ind $\left./ \mathrm{m}^{2}\right)$, S. chloronatus $\left(0.2 \mathrm{ind} / \mathrm{m}^{2}\right)$, as well as the starfish Acanthaster planci. In massive colonies of Porites and Platygyra, polychetes S. giganteus and bivalve's A. ventricosa and Barbatia velata were detected, on branching colonies, crinoids Comatula pectinata and Oxycianthus bennetti. Between the coral colonies, the nudibranchs Gymnodoris ceylonica, Phyllidia bourgini were seen.

For reef slope platform zone: At a distance of 100 - $160 \mathrm{~m}$ from the shoreline, with the replacement of the rocky and organic-detrital substrate with corallogenous silted detritus, only settlements of individual colonies scleractinian Stylophora pistillata, Acropora secale, L. phrygia, F. speciosa, F. abdita, G. fascicularis, Lobophylla hattai, Echinopora lamellosa, T. peltata, Goniopora tenuidens, F. speciosa, and Tubastrea nigrescens; single Fungia paumotensis and gorgonians J. fragilis, Subergorgia tuberosa, Ctenocellia lira, the latter dominates in terms of population density, up to $3-5 \mathrm{ind} / \mathrm{m}^{2}$. Bivalves Malleus malleus $\left(0.5 \mathrm{ind} / \mathrm{m}^{2}\right)$, Isognomon isognomum L. cristagalli and Pteria penguin were found on the branches of gorgonians. On the reefs with weak 
silting of the slope platform, most common are settlements of small single corals Heteropsammia cochlea and Bathyactis palifera (from 400 to $800 \mathrm{ind} / \mathrm{m}^{2}$ ) and tufts of sea grass Halophila decipiens between them.

\section{Discussion}

The adjoining structureless reefs' morphology, degree of development of coral structures, qualitative and quantitative composition of corals is comparable to other Vietnam reefs [5] [16]-[18]. Of 140 - 170 scleractinian species found on these reefs, $47 \%-68 \%$ are also marked on the reefs of Nha Trang, Con Dao island, the Gulf of Thailand and the Gulf of Tonkin [4] [8]. For small reefs of $70-160 \mathrm{~m}$ from the shoreline (maximum $200 \mathrm{~m}$ ), this is quite a high rate of species diversity. Only Acroporidae are represented in 40 species, which makes up $78 \%$ of the total composition of these scleractinian on the reefs of the entire Vietnam [8] [19]. The abundance of Acroporidae is an evidence of satisfactory biotic and abiotic conditions on these reefs. These corals are among the first ones to respond to environmental change, especially to anthropogenic pollution and increasing water eutrophication. It is known that in contaminated areas, these corals are absent or very few [6] [20]-[23]. The studied reefs are characterized by explicit bionomic zoning, high species richness and extent of substrate coverage by corals. Participation of various corals in most of the coverage of the surface of the substrate in all zones also confirms the optimal conditions for the formation of these reefs (Figure 3).

The similarity of the composition and structure of communities of these reefs clearly show almost the same index of biodiversity and species richness of the Scleractinia (Figure 4, Figure 5). This situation, according to

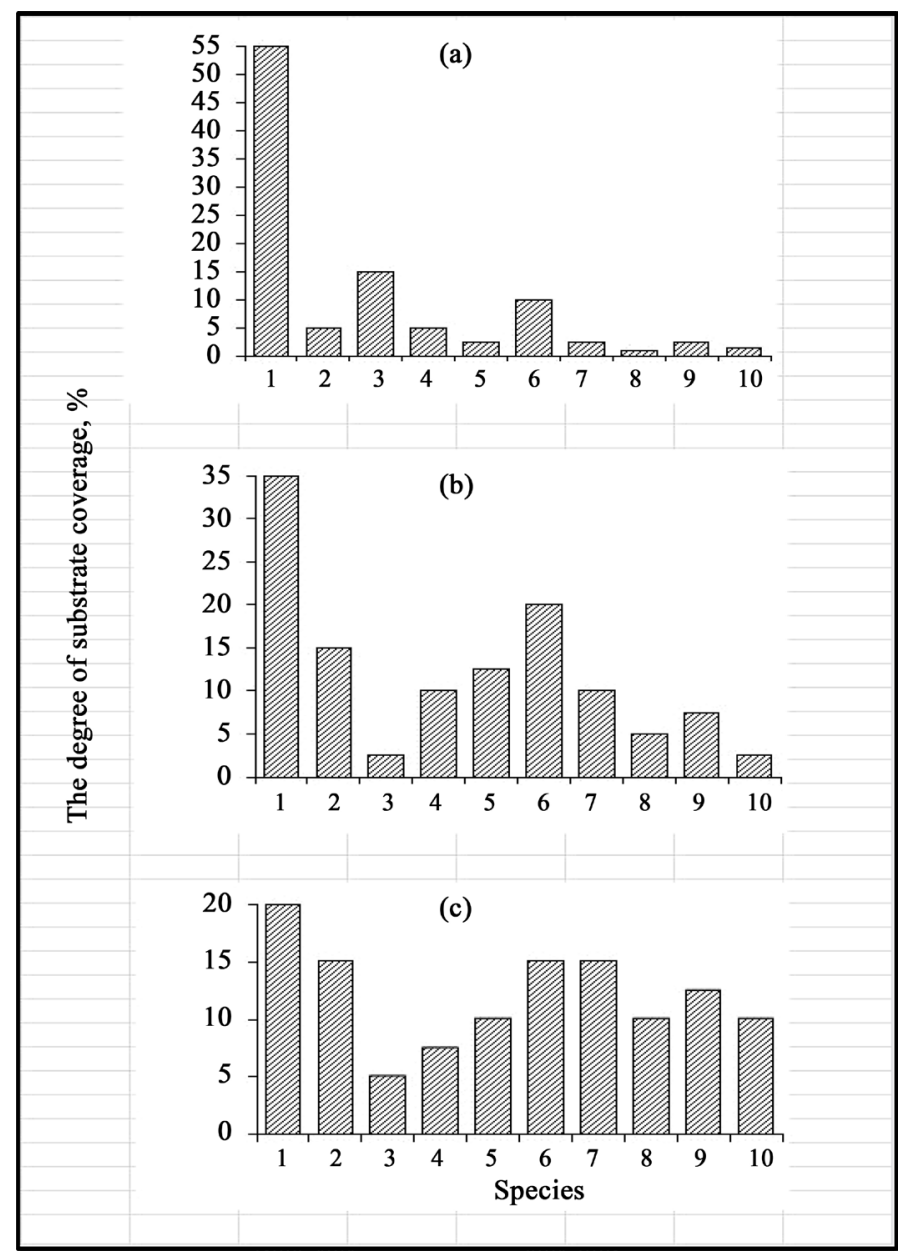

Figure 3. The rank distribution of skleraktinij expressed in substrate coverage corals in different reef zones: (a) zone Acropora cytherea + Acropora microphthalma; (b) zone Acropora nobilis; (c) polyspecific zone of corals settlements. $1-A$. microphthalma, 2-A. nobilis, 3-A. valenciennesi, 4-Montipora aequituberculata, 5-M. hispida, 6-Hydnophora rigida, 7-Porites cilindrica, 8-P. rus, 9-Platygyra daedalea, 10-Favia maxima. 


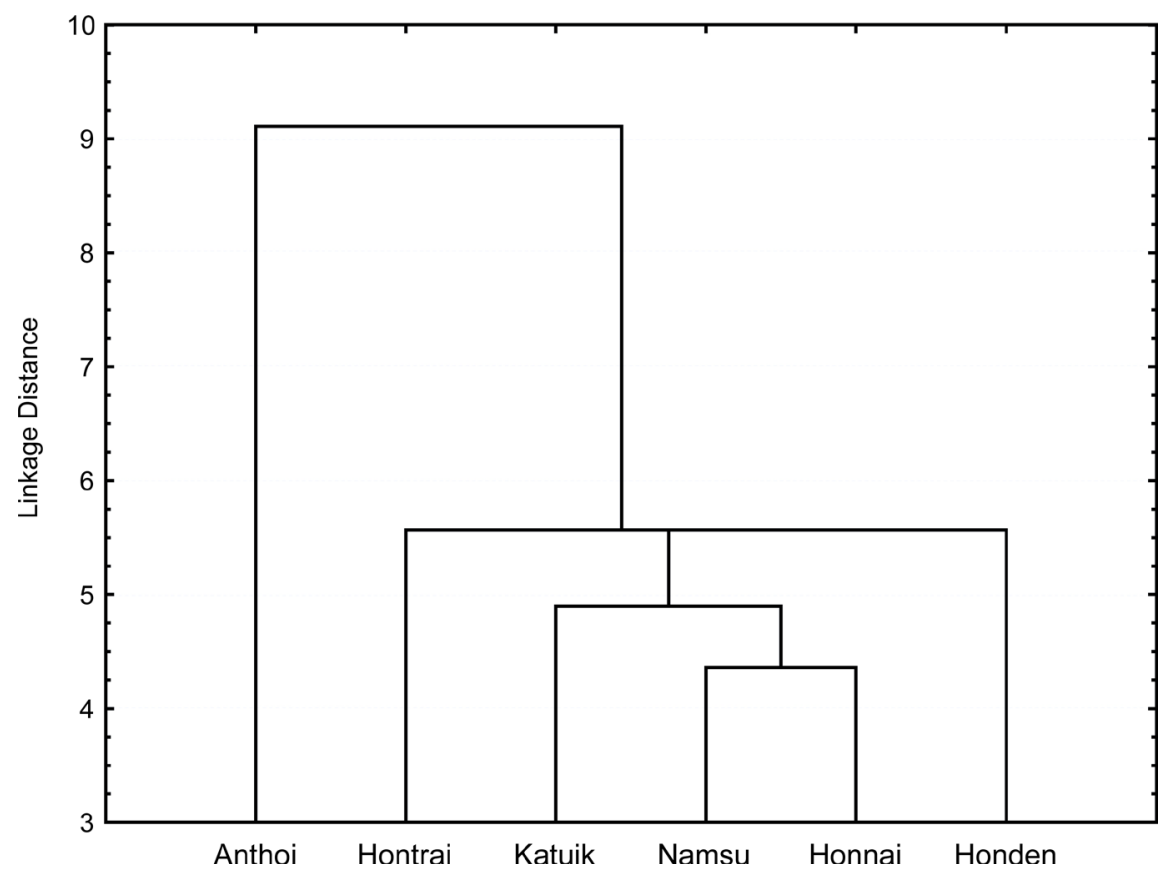

Figure 4. Cluster diagram the similarity species composition of scleractinian.

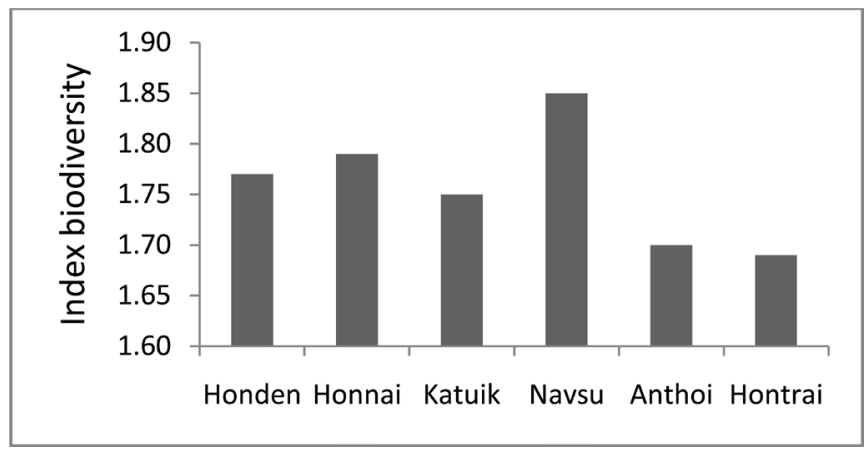

Figure 5. Diagram of species diversity scleractinian.

some researchers, is characteristic of the optimal climax conditions on the reef [15] [16] [24]-[26]. The slopes of the reefs studied, just like the slope of the majority of reefs of the Indo-Pacific, are characterized by a set of certain species corals, and a particularly rich species diversity [16] [19] [26]-[32].

Bionomic vertical zonation expressed on unstructured reefs, is largely determined by the geomorphological features of the stony-coral substrate of the underwater slope [3] [10] [33] [34]. A similar pattern of vertical bionomic zoning in accordance with the zonal distribution of environmental factors (substrate, wave conditions, degree of sedimentation, light) was observed in the Indian Ocean reefs [3] [11] [35], as well as in a number of areas in the Pacific and the Caribbean [36] [37].

\section{Conclusions}

Unstructured (incrusting) reefs have stable species composition and community structure in the same bionomic areas as conventional reefs. They are characterized by high species diversity, including more than a third of all species of Pacific reef-building scleractinian [18] [27] [28] [38]. Their calcareous skeleton ("framework building" [27]) is under construction, grouting and filling reef deposits [1], and eventually, under certain conditions, they can form into structural reefs (Figure 6). Such reefs cannot always be distinguished from the actual structure reefs, or from different stages of reef development as "coral layers" and "specialized settlements" [39], so a new term to describe them was needed, "Unstructured reef" [2]. Such cortical reefs, along with regular structural 


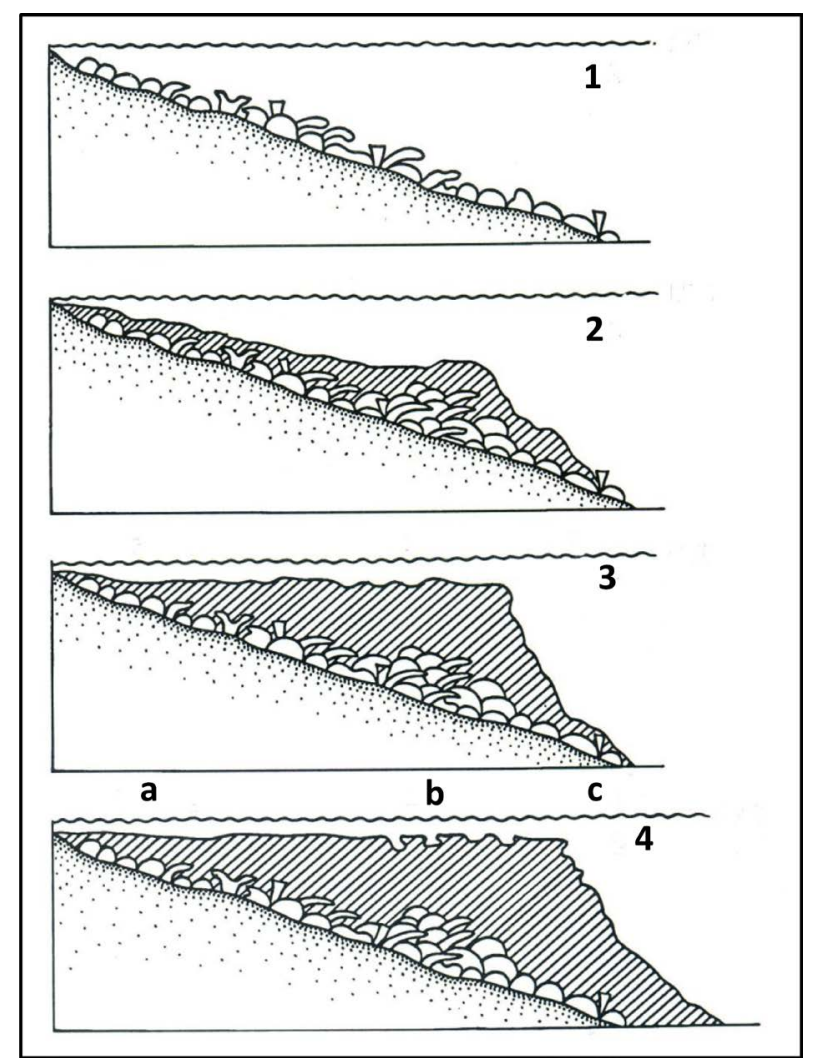

Figure 6. Schema of the various stages of development. 1-surface layer of corals to substrate, 2-primary reef framework, 3-young adjacent reef emerging zoning, 4—structural reef with clear zoning: a-lagoon, b-reef flat, c-reef slope.

reefs, are widely distributed along the continental and island shores of the Indo-Pacific [2] [3] [35] [40].

The composition and distribution of coral reefs and associated benthos of the reef communities form the heterotrophic components of the internal parts of the reef and the autotrophic ones of the external parts, a common component of the trophic ecosystem of the regular reefs [18] [41]-[43]. Unstructured reefs are characterized by the same regularity of the trophic structure in terms of a clear bionomic zoning scheme on reefs throughout the Indo-Pacific in general.

\section{Acknowledgements}

The authors express their gratitude to my colleagues I. Budin, A. Goloseev, V. Brykov, L. V. Ken, N. Selin and Yu. Yakovlev for help with field studies.

\section{References}

[1] Wainwright, S.A. (1965) Reef Communities Visited by the Israel South Red Expedition, 1962. Bulletin of the Sea Fisheries Research Station Israel, 38, 40-53.

[2] Latypov, Yu.Ya. (1995) Community Structure of Scleractinian Reefs in the Baitylong Archipelago (South China Sea). Asian Marine Biology, 12, 27-37.

[3] Latypov, Yu.Ya. (2014) Scleractinian Corals of Vietnam. Science Publishing Group, 1-481.

[4] Latypov, Yu.Ya. (2005) Reef-Building Corals of Vietnam as a Part of the Indo-Pacific Reef Ecosystem. Russian Journal of Marine Biology, 31, S34-S40. http://dx.doi.org/10.1007/s11179-006-0013-5

[5] Latypov, Yu.Ya. (2008) Species Composition and Structure of Coral Community of a Platform Reef at Bach Long Vi Island in the South China Sea. Russian Journal of Marine Biology, 34, 249-253. http://dx.doi.org/10.1134/S1063074008040068

[6] Latypov, Yu.Ya. (2012) Encrusting Protected Reef Hon Nai in Cam Ranh Bay in the South China Sea. Natural Science, 4, 14-21. 
[7] Vo, S.T. and Nguyen, H.Y. (1995) Corals Reefs and Reef Building Corals of Vietnam. Collection of Marine Research Works, 1, 101-110.

[8] Latypov, Yu.Ya. and Long, P.Q. (2010) The Common Hard Corals of Vietnam. Ministry of Agriculture and Rural Development, Hanoi, $281 \mathrm{p}$.

[9] Latypov, Yu.Ya. (1982) Species Composition and Distribution of Scleractinians in Reefs of the Khanh Hoa Province (South Vietnam). Biologia Morya, 6, 5-12.

[10] Latypov, Yu.Ya. (1992) Reefs and Communities of Scleractinians in the Western Part of the Bai Thu Long Archipelago (South China Sea). Biologia Morya, 1-2, 17-26.

[11] Latypov, Yu.Ya. (1986) Coral Communities of the Namsu Islands (Gulf of Siam, South China Sea). Marine Ecology Progress Series, 29, 261-270.

[12] Ken, L.V. (1991) The Stony Corals in the Sea of Vietnam. Marine Environment and Research (1986-1990). Scientific and Technic Publishing House, Hanoi, 127-135.

[13] Loya, Y. and Slobodkin, L. (1971) The Coral Reefs of Elate (Gulf of Elate. Red Sea). Symposium of the Zoological Society of London, 28, 117-140.

[14] Mandaville, S.M. (2002) Benthic Macroinvertebrates in Freshwater. Taxa Tolerance Values, Metrics, and Protocols, Project H-1. Soil \&Water Conservation Society of Metro Halifax, Nova Scotia, A58.

[15] Pichon, M. (1981) Dynamic Aspects of Coral Reef Benthic Structures and Zonation. Proceedings of the Fourth International Coral Reef Symposium, 1981, 581-594.

[16] Latypov, Yu.Ya. (1993) Benthic Communities of the Corals Reef of the Kondao Islands in the South China Sea, Russian Journal of Marine Biology, 5-6, 40-53.

[17] Latypov, Yu.Ya. (2000) Macrobenthos Communities on Reefs of the AnThoi Archipelago of the South China Sea. Russian Journal of Marine Biology, 26, 18-26. http://dx.doi.org/10.1007/BF02759489

[18] Latypov, Yu.Ya. (2003) Reef-Building Corals and Reefs of Vietnam: 1. The Gulf of Thailand. Russian Journal of Marine Biology, 29, S22-S33.

[19] Latypov, Yu.Ya. (2014) Species Composition and Distribution of Scleractinian on Reefs of Wan Phong and Nha Trang Bays (South Vietnam). International Journal of Advanced Research in Biological Sciences, 1, 1-14.

[20] Cortes, J. and Risk, M.-J. (1985) A Reef under Siltation Stress: Cahuita, Costa Rica. Bulletin of Marine Science, 36, 339-356.

[21] Tomascik, T. and Sander, F. (1987) Effect of Eutrophication on Reef-building Corals. 3. Reproduction of the Reefbuilding Coral Poritesporites. Marine Biology, 94, 77-94.

[22] Pavlov, D.S., Smurov, A.V., Ilyash, L.V., et al. (2004) Present-Day State of Coral Reefs in Nha Trang Bay (Southern Vietnam) and Possible Reasons for the Disturbance of Scleractinian Habitats. Biologiya Morya, 30, 60-67. http://dx.doi.org/10.1023/b:rumb.0000020568.41920.e2

[23] Latypov, Yu.Ya. (2006) Changes in the Composition and Structure of Coral Communities of Mju and Moon Islands, Nha Trang Bay, South China Sea. Russian Journal of Marine Biology, 32, 269-275. http://dx.doi.org/10.1134/S1063074006050014

[24] Grigg, R.W. and Maragos, J.E. (1974) Recolonization of Corals on Lava in Hawaii. Ecology, 55, 387-395. http://dx.doi.org/10.2307/1935226

[25] Mergner, H. (1979) Quantitative okologische Analyseeines Riffiagunenarealsbei Aqaba (Gulf von Aqaba, Rotes Meer). Helgoland Wiss. Meer., 32, 476-507.

[26] Sheppard, C.R.C. (1982) Coral Population on the Reef Slopes and Their Major Controls. Marine Ecology-Progress Series, 7, 83-115.

[27] Loya, Y. (1972) Community Structure and Species Diversity of Hermatypic Corals at Eilat, Red Sea. Marine Biology, 13, 100-113.

[28] Pichon, M. (1974) Dynamics of Benthic Communities in the Coral Reefs of Tulear (Madagascar): Succession and Transformation of the Biotopes trough Reef Tract Evolution. Proceedings of the 2nd International Coral Reef Symposium, Brisbane, 1974, 55-68.

[29] Bouchon, C. (1981) Quantitative Study of the Scleractinian Coral Communities of a Fringing Reef of Reunion Island (Indian Ocean). Marine Ecology-Progress Series, 1, 273-288.

[30] Latypov, Yu.Ya. (1987) Species Composition and Distribution of Scleractinian in Islands Socotra. The Soviet Journal of Marine Biology, 4, 35-41.

[31] Latypov, Yu.Ya. (1987) Scleractinian Corals of South Vietnam. The Soviet Journal of Marine Biology, 13, $246-252$.

[32] Latypov, Yu.Ya. (2007) Coral Reefs of Vietnam. Nauka, Moskow, 179 c. (In Russian) 
[33] Latypov, Yu.Ya. (2015) Particular Qualities of Forming of Reefs and Coral Communities in the North and Central Vietnam. International Journal of Ecosystem, 5, 66-74.

[34] Jones, O.A., Randall, Y.M., Cheng, H.T., et al. (1972) A Marine Biological Survey of Southern Taiwan with Emphasis on Corals and Fishes. Institute of Oceanography and National Taiwan University Special Publications, 1, 1-93.

[35] Dai, C.F. (1993) Patterns of Coral Distribution and Benthic Space Partitioning on the Fringing Reefs of Southern Taiwan. Marine Ecology, 14, 185-204.

[36] Sakai, K., Yeemin, T., Svidvong, A., et al. (1986) Distribution and Community Structure of Hermatypic Corals in the Sichang Islands, Inner Part of the Gulf of Thailand. Galaxea, 5, 27-74.

[37] Lang, J. (1974) Zonation at the Base of a Reef. American Science, 62, 272-281.

[38] Liddel, W.D. and Ohlhorst, S.L. (1987) Patterns of Reef Coral Community Structure, North Jamaica. The Biological Bulletin, 40, 311-329.

[39] Latypov, Yu.Ya. and Selin, N.I. (2011) Current Status of Coral Reefs of Island in the Gulf of Siam and Southern Vietnam. Russian Journal of Marine Biology, 37, 255-262. http://dx.doi.org/10.1134/S1063074011040080

[40] Vo, S.T. and Hodgson, G. (1997) Coral Reefs of Vietnam: Recruitment Limitation and Physical Forcing. Proceedings of the 8th International Coral Reef Symposium, 1997, 477-482.

[41] Pichon, M. (1977) Physiography, Morphology and Ecology of the Double Barrier Reef of Port Bohol (Philippines). Proceedings of the Third International Coral Reef Symposium, Miami, 1977, 261-267.

[42] Sorokin, Yu.I. (1990) Coral Reefs Ecosystems. Nauka, Moskow, 503 p.

[43] Latypov, Yu.Ya. (2009) Species Composition and Distribution of Scleractinian on the Reefs of the Seychelles Islands. Russian Journal of Marine Biology, 35, 454-462. http://dx.doi.org/10.1134/S1063074009060029 